\title{
Nocardiopsis aegyptia sp. nov., isolated from marine sediment
}

\author{
Soraya A. Sabry, ${ }^{1}$ Nevine B. Ghanem, ${ }^{1}$ Gehan A. Abu-Ella, ${ }^{1}$ \\ Peter Schumann, ${ }^{2}$ Erko Stackebrandt ${ }^{2}$ and Reiner M. Kroppenstedt ${ }^{2}$ \\ ${ }^{1}$ Alexandria University, Faculty of Science, Division: Microbiology, PO Box, Alexandria, Egypt \\ ${ }^{2}$ DSMZ - Deutsche Sammlung von Mikroorganismen und Zellkulturen, Mascheroder Weg $1 \mathrm{~b}$, \\ 38124 Braunschweig, Germany
}

Correspondence

Reiner M. Kroppenstedt kdt@dsmz.de

\begin{abstract}
An actinomycete, strain SNG49 ${ }^{\top}$, was isolated from marine sediment of Abu Qir Bay, on the western seashore of Alexandria, Egypt. The bacterium was aerobic and Gram-positive. It produced beige to light-yellow aerial mycelium, brown substrate mycelium and straight to flexuous hyphae, but no specific spore chains. 16S rDNA sequence analysis and chemotaxonomic markers were consistent with classification of strain $\mathrm{SNG}_{4} 9^{\top}$ in the genus Nocardiopsis, i.e. mesodiaminopimelic acid; no diagnostic sugars; phosphatidylcholine, phosphatidylmethylethanolamine, phosphatidylinositol, phosphatidylglycerol and diphosphatidylglycerol as polar lipids; menaquinones of the MK-10 series from MK-10 $\left(\mathrm{H}_{0}\right)$ to $\mathrm{MK}-10\left(\mathrm{H}_{8}\right)$; and iso/anteiso-branched and 10-methyl-branched fatty acids, the principal fatty acids being anteiso-17:0 and tuberculostearic acid. Nocardiopsis lucentensis and Nocardiopsis alba are the phylogenetic neighbours of strain SNG49 ${ }^{\top}$, respectively showing $98 \cdot 8$ and $98 \cdot 7 \% 16 \mathrm{~S}$ rRNA gene sequence similarity; however, moderate DNA-DNA reassociation values between these two species and strain SNG $49^{\top}$ (44 and $60 \%$, respectively) showed that strain SNG $49^{\top}$ could be clearly separated from them. These data, together with distinct physiological traits, led to the conclusion that this isolate represents a novel species within the genus Nocardiopsis, for which the name Nocardiopsis aegyptia is proposed. The type strain is SNG $49^{\top}\left(=\mathrm{DSM} 44442^{\top}=\mathrm{NRRL} \mathrm{B}-24244^{\top}\right)$.
\end{abstract}

Nocardiopsis strains are distributed ubiquitously in the environment (Kroppenstedt \& Evtushenko, 2002). They are frequently isolated from habitats with moderate to high salt concentrations such as saline soil or marine sediments (Al-Zarban et al., 2002; Al-Tai \& Ruan, 1994; Evtushenko et al., 2000) and salterns (Chun et al., 2000). The aim of this study was to classify strain $\mathrm{SNG} 49^{\mathrm{T}}$, a novel strain isolated from marine sediment, by morphological, physiological, chemotaxonomic and molecular biological methods.

Strain SNG49 ${ }^{\mathrm{T}}$ was isolated from marine sediment taken at a depth of $20 \mathrm{~cm}$ on the seashore of Abu Qir Bay, west of Alexandria, Egypt, using dilution plating on ISP agar supplemented with $5 \% \mathrm{NaCl}$ (Shirling \& Gottlieb, 1966). Determination of morphological traits and colours of the aerial and substrate mycelium, as well as of soluble pigments, was done as described by Shirling \& Gottlieb (1966). Biochemical tests were performed according to Kroppenstedt \& Evtushenko (2002) and Al-Zarban et al.

Abbreviations: DPG, diphosphatidylglycerol; PC, phosphatidylcholine; PG, phosphatidylglycerol; PI, phosphatidylinositol; PME, phosphatidylmethylethanolamine.

The GenBank accession number for the $16 \mathrm{~S}$ rRNA gene sequence of strain DSM $44442^{\top}$ is AJ539401.
(2002). Strain $\mathrm{SNG} 49^{\mathrm{T}}$ showed the typical macroscopic and microscopic appearance of most species of the genus Nocardiopsis (Meyer, 1994), with dirty white aerial mycelium, which becomes light- to dark-yellowish grey in ageing cultures grown on GYM medium ( $4 \mathrm{~g}$ glucose, $4 \mathrm{~g}$ yeast extract, $10 \mathrm{~g}$ malt extract $\mathrm{l}^{-1}$ ). The substrate mycelium was brownish. No pigments were released into the medium. The hyphae of the aerial mycelium were straight to flexuous. In older cultures, hyphae of aerial mycelium disintegrated into spore-like structures.

Carbon sources utilized by strain $\mathrm{SNG}_{4} 9^{\mathrm{T}}$ are listed in Table 1 . The strain grew at 10 and $40{ }^{\circ} \mathrm{C}$ and in $5 \% \mathrm{NaCl}$, but was not able to grow in the presence of $10 \% \mathrm{NaCl}$. Optimal growth was observed at $25-28{ }^{\circ} \mathrm{C}$.

Cell material used for chemotaxonomic analyses was obtained from cultures grown in trypticase soy broth (BBL) for 4 days at $28{ }^{\circ} \mathrm{C}$ on a rotary shaker. Cells were harvested by centrifugation and washed twice with distilled water. Analyses of amino acid and sugars were carried out using the methods of Staneck \& Roberts (1974). Menaquinones and polar lipids were extracted following the procedure of Minnikin et al. (1984). Polar lipids and menaquinones were respectively analysed by TLC (Minnikin 
Table 1. Diagnostic characteristics of Nocardiopsis species that are phylogenetically related to strain DSM $44442^{\top}$ and of the type strain of the type species, $N$. dassonvillei subsp. dassonvillei DSM $43111^{\top}$

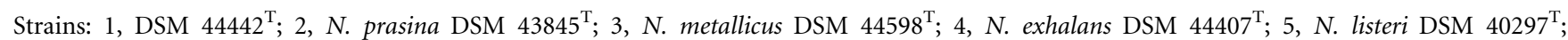
6, N. alba DSM $43377^{\mathrm{T}} ; 7$, N. tropica DSM 44381 $;$; , N. umidischolae DSM 44362 ${ }^{\mathrm{T}}$; 9, N. lucentensis DSM 44048 ${ }^{\mathrm{T}}$; 10, N. dassonvillei subsp. dassonvillei DSM 43111 ${ }^{\mathrm{T}}$. Data were taken from Kroppenstedt \& Evtushenko (2002), Peltola et al. (2001) (N. exhalans and N. umidischolae) and Schippers et al. (2002) (N. metallicus). +, Positive; -, negative; V, variable; ND, no data. None of the strains grew at $45^{\circ} \mathrm{C}$.

\begin{tabular}{|c|c|c|c|c|c|c|c|c|c|c|}
\hline Characteristic & 1 & 2 & 3 & 4 & 5 & 6 & 7 & 8 & 9 & 10 \\
\hline Aerial hyphae & + & + & + & + & - & + & + & + & + & + \\
\hline \multicolumn{11}{|l|}{ Growth in/at: } \\
\hline $10^{\circ} \mathrm{C}$ & + & - & + & + & + & - & $\mathrm{v}$ & + & + & $\mathrm{v}$ \\
\hline $10 \% \mathrm{NaCl}$ & - & + & + & + & - & - & + & - & + & + \\
\hline Major menaquinones & $\begin{array}{l}10 / 6 \\
10 / 8^{*}\end{array}$ & $\begin{array}{l}10 / 4 \\
10 / 6\end{array}$ & $\mathrm{ND}$ & $\begin{array}{c}10 / 6,19 / 8, \\
19 / 4,9 / 6,9 / 8\end{array}$ & $\begin{array}{l}10 / 0 \\
10 / 2\end{array}$ & $\begin{array}{l}10 / 4 \\
10 / 6\end{array}$ & $\begin{array}{l}10 / 6 \\
10 / 8\end{array}$ & $\begin{array}{l}10 / 6,10 / 4 \\
10 / 8,11 / 6\end{array}$ & $\begin{array}{l}10 / 6 \\
10 / 8\end{array}$ & $\begin{array}{l}10 / 4 \\
10 / 6\end{array}$ \\
\hline \multicolumn{11}{|c|}{ Carbon source utilization: $\dagger$} \\
\hline L-Arabinose & + & + & $\mathrm{ND}$ & + & + & - & + & + & - & + \\
\hline Galactose & + & - & + & - & + & - & + & + & - & + \\
\hline Glycerol & + & + & $\mathrm{ND}$ & ND & - & + & + & ND & + & + \\
\hline Inositol & + & - & $\mathrm{ND}$ & - & - & - & - & - & + & - \\
\hline D-Lactose & + & - & $\mathrm{ND}$ & - & + & - & - & + & - & - \\
\hline Mannitol & + & + & + & + & - & + & + & + & + & + \\
\hline D-Mannose & + & - & $\mathrm{ND}$ & + & - & - & + & + & + & - \\
\hline L-Rhamnose & + & - & + & + & + & - & + & + & + & + \\
\hline Sucrose & + & + & + & + & - & + & + & + & + & + \\
\hline D-Xylose & + & + & + & + & + & - & + & + & - & + \\
\hline
\end{tabular}

*Significant amounts of other menaquinones are also found (see species description).

$\dagger$ Determined using carbon sources at $1 \%$.

et al., 1977) and HPLC (Kroppenstedt, 1982, 1985). Fatty acids were analysed according to the methods of Miller (1982) and Sasser (1990). The presence of mycolic acids was determined by the method of Minnikin et al. (1975).

Whole-cell hydrolysates of strain $\mathrm{SNG} 49^{\mathrm{T}}$ contained mesodiaminopimelic acid as the diamino acid in the peptidoglycan. Galactose, glucose and ribose were the only sugars found in the hydrolysates (cell wall type III, according to Lechevalier \& Lechevalier, 1980). The diagnostic sugars arabinose, xylose and madurose could not be detected. Strain SNG49 ${ }^{\mathrm{T}}$ synthesized menaquinones from MK$10\left(\mathrm{H}_{0}\right)$ to $\mathrm{MK}-10\left(\mathrm{H}_{8}\right)$ (for quantitative distribution, see the species description). The polar lipids comprised the diagnostic phospholipids phosphatidylcholine (PC) and phosphatidylmethylethanolamine (PME) and the nondiagnostic phosphatidylinositol (PI), phosphatidylglycerol (PG) and diphosphatidylglycerol (DPG) (i.e. phospholipid type III, according to Lechevalier et al., 1977). This pattern matched quite well with those found in Nocardiopsis species (Kroppenstedt \& Evtushenko, 2002). The fatty acid composition revealed mainly iso/anteiso-branched and 10-methyl-branched fatty acids. The principal fatty acids were 14-methyl hexadecanoic acid (anteiso-17:0) and 10-methyl octadecanoic acid (tuberculostearic acid). This combination of fatty acids is diagnostic for species of the genus Nocardiopsis (fatty acid pattern 3d sensu
Kroppenstedt \& Evtushenko, 2002). Qualitative and quantitative distributions are given in the species description. Mycolic acids were not detected. All chemotaxonomic properties of strain $\mathrm{SNG}_{4} 9^{\mathrm{T}}$ were consistent with its classification in the genus Nocardiopsis (Kroppenstedt \& Evtushenko, 2002).

Genomic DNA extraction, PCR-mediated amplification of the $16 \mathrm{~S}$ rDNA and purification of PCR products were carried out as described previously (Rainey et al., 1996). The ae2 editor (Maidak et al., 1999) was used to align the almost complete $16 \mathrm{~S}$ rDNA sequence of strain SNG49 ${ }^{\mathrm{T}}$ (1487 nt) against the 16S rDNA gene sequences of representatives of the main actinobacterial lineages and then against sequences of members of the genus Nocardiopsis. Phylogenetic analyses followed described methods (De Soete, 1983; Felsenstein, 1993). With intrageneric sequence similarities ranging between 95.9 and $98.8 \%$, strain $\mathrm{SNG} 49^{\mathrm{T}}$ was most closely related to members of the genus Nocardiopsis, especially to Nocardiopsis lucentensis (98.8\% similarity) and Nocardiopsis alba (98.7\%). These similarity values are lower than those found for some other individual pairs of Nocardiopsis species, e.g. Nocardiopsis tropica DSM $44381^{\mathrm{T}}$ and Nocardiopsis umidischolae DSM $44362^{\mathrm{T}}$ (99.2 \%); Nocardiopsis metallicus DSM $44598^{\mathrm{T}}$ and Nocardiopsis exhalans DSM $44407^{\mathrm{T}}$ (99.5\%); or N. metallicus DSM $44598^{\mathrm{T}}$ and Nocardiopsis prasina DSM $43845^{\mathrm{T}}(99 \cdot 4 \%)$. 


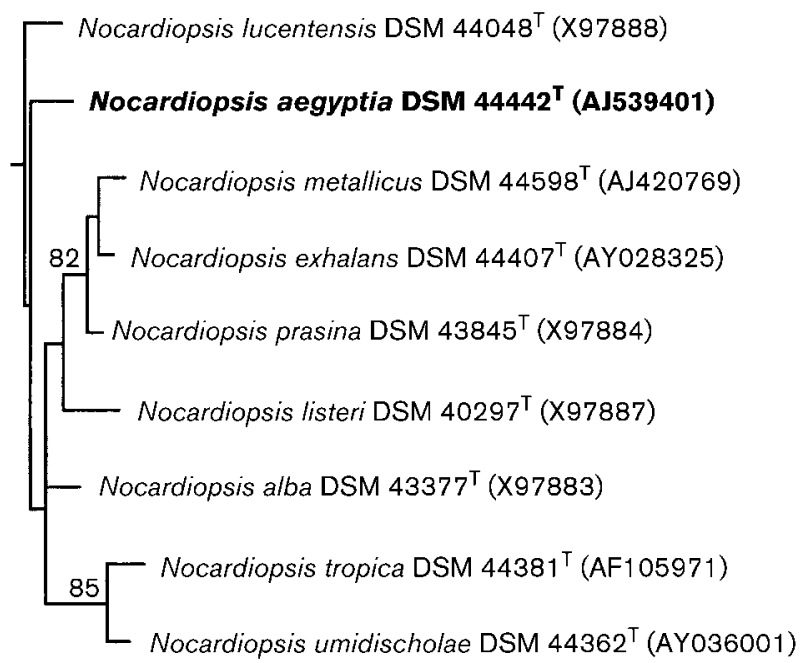

$2 \%$

Fig. 1. 16S rDNA dendrogram (De Soete, 1983) displaying the phylogenetic position of strain DSM $44442^{\top}$ and phylogenetically related members of the genus Nocardiopsis. Numbers at nodes indicate percentages of bootstrap samplings, derived from 1000 resamplings; values less than $50 \%$ are not shown. Bar, $2 \%$ sequence divergence. More distantly related members of the genus served as a root.

Both distance-matrix and maximum-likelihood analyses gave consistent results in that strain $\mathrm{SNG} 49^{\mathrm{T}}$ clustered adjacent to the type strains of $N$. lucentensis, $N$. alba and related strains, but bootstrap values for the branching points of most Nocardiopsis type strains were low $(<50 \%)$ (Fig. 1).

DNA was isolated by chromatography on hydroxyapatite by the procedure of Cashion et al. (1977). DNA-DNA hybridization was carried out as described by Huß et al. (1983) using a Gilford 2600 spectrophotometer equipped with a Gilford 2527-R thermoprogrammer and plotter. Reassociation was performed under optimal conditions $\left[2 \times \mathrm{SSC}+10 \%(\mathrm{v} / \mathrm{v}) \mathrm{DMSO}\right.$ at $\left.68^{\circ} \mathrm{C}\right]$ and was recorded using a Gilford 2600 spectrophotometer (Huß et al., 1983; Jahnke, 1992). The DNA-DNA relatedness of strain SNG49 ${ }^{\mathrm{T}}$ to N. lucentensis DSM $44048^{\mathrm{T}}$ was $44 \%$, whereas the value for N. alba DSM $43377^{\mathrm{T}}$ was $60 \%$. These values are below the threshold value of about $70 \%$, recommended by Wayne et al. (1987) for assigning strains to the same species.

Automated ribotyping was carried out with the RiboPrinter microbial characterization system (Qualicon; DuPont). Sample preparation and analysis were performed according to the manufacturer's instructions using PvuII to generate restriction fragments. The RiboPrint pattern of strain SNG49 ${ }^{\mathrm{T}}$ confirmed that this strain differed from the type strains of both phylogenetic neighbours and representatives of other Nocardiopsis species (Fig. 2).

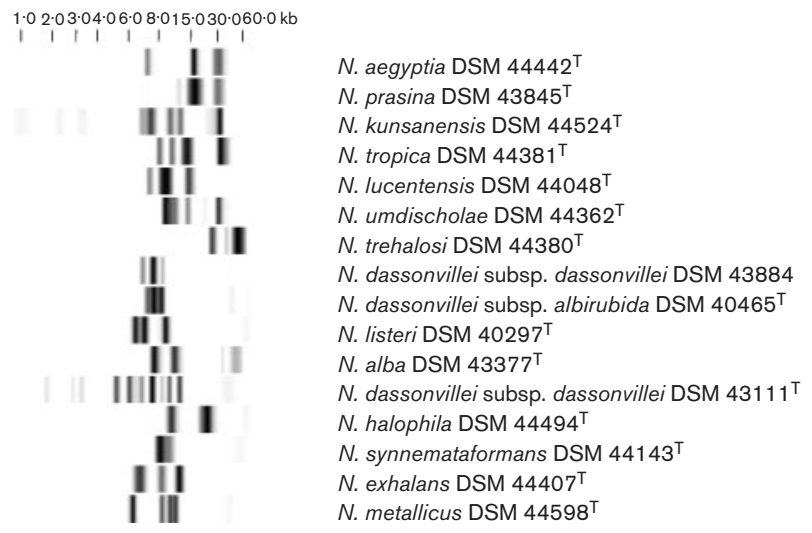

Fig. 2. RiboPrint patterns of Nocardiopsis strains. Fragments were generated from DNA by Pvull.

Based on the phenotypic, chemotaxonomic and genotypic data, it is concluded that $\mathrm{SNG} 49^{\mathrm{T}}$ represents a novel species in the genus Nocardiopsis; the name Nocardiopsis aegyptia sp. nov. is proposed. Isolate $\mathrm{SNG} 49^{\mathrm{T}}$ is currently the only strain of this species.

The phylogenetic position of this organism is within the cluster defined by N. lucentensis and N. alba (Fig. 1). Strain SNG $49^{\mathrm{T}}$ can be differentiated from described Nocardiopsis species by a combination of morphological, physiological and chemotaxonomic data: by morphology from Nocardiopsis synnemataformans, which produces synnemata, and Nocardiopsis listeri, which does not produce a welldeveloped aerial mycelium; by physiology from Nocardiopsis halophila and Nocardiopsis halotolerans, which can grow at $15 \% \mathrm{NaCl}$ or higher; and by the ability of strain SNG $49^{\mathrm{T}}$ to use nearly all of the carbon sources investigated, except L-arabinose (see Table 1). Chemotaxonomically, Nocardiopsis species fall into two groups: those that synthesize mainly menaquinones with highly saturated isoprenoid side-chains, i.e. SNG49 ${ }^{\mathrm{T}}$, Nocardiopsis dassonvillei subsp. dassonvillei, N. alba, Nocardiopsis kunsanensis, N. prasina, N. lucentensis, Nocardiopsis trehalosi, N. tropica and N. halophila; and others, including N. halotolerans, N. dassonvillei subsp. albirubida, N. listeri and N. synnemataformans, that contain non-saturated isoprene units (Kroppenstedt \& Evtushenko, 2002).

\section{Description of Nocardiopsis aegyptia sp. nov.}

Nocardiopsis aegyptia (ae.gyp.ti'a. L. fem. adj. aegyptia from Egypt, referring to the country of isolation).

Aerobic, Gram-positive, non-motile actinomycete that forms dirty white aerial mycelium, becoming light-yellowish grey in ageing cultures. No endo- or exopigments produced. Hyphae of the aerial mycelium are straight to flexuous. In older cultures, hyphae of aerial mycelium disintegrate into spore-like structures. Optimal growth obtained on GYM at $28^{\circ} \mathrm{C}$. Grows at $10^{\circ} \mathrm{C}$ and in $5 \%$ 
$\mathrm{NaCl}$, but not at $45^{\circ} \mathrm{C}$ or in $10 \% \mathrm{NaCl}$. Physiological reactions are indicated in Table 1 . Whole cell hydrolysates contain meso-diaminopimelic acid, but no diagnostic sugars. Menaquinones are: $\mathrm{MK}-10\left(\mathrm{H}_{0}\right), 6 \%$; $\mathrm{MK}-10\left(\mathrm{H}_{2}\right)$, $7 \%$; MK- $10\left(\mathrm{H}_{4}\right), 19 \%$; MK- $10\left(\mathrm{H}_{6}\right), 38 \%$; and MK- $10\left(\mathrm{H}_{8}\right)$, $30 \%$. Traces of MK-9 $\left(\mathrm{H}_{4}\right)$ and MK-9 $\left(\mathrm{H}_{6}\right)$ are also found. Polar lipids are PC, PME, PI, PG and DPG. The fatty acid composition ( $>1 \%$ of total) is as follows: iso- $\mathrm{C}_{14: 0}$ $(12 \cdot 12 \%)$, iso- $\mathrm{C}_{15: 0}(1 \cdot 70 \%)$, iso- $\mathrm{C}_{16: 0}(19 \cdot 14 \%)$, iso$\mathrm{C}_{17: 0}(5 \cdot 10 \%)$, iso- $\mathrm{C}_{18: 0}(3 \cdot 16 \%)$, anteiso- $\mathrm{C}_{15: 0}(6 \cdot 49 \%)$, anteiso- $\mathrm{C}_{17: 0}(17 \cdot 85 \%)$, anteiso- $\mathrm{C}_{17: 1}(1 \cdot 35 \%), 10$-methyl $\mathrm{C}_{16: 0}(1 \cdot 50 \%), 10$-methyl $\mathrm{C}_{17: 0}(2 \cdot 58 \%), 10$-methyl $\mathrm{C}_{18: 0}$ $(12 \cdot 19 \%), \mathrm{C}_{16: 0}(4 \cdot 21 \%), \mathrm{C}_{16: 1}(1 \cdot 10 \%), \mathrm{C}_{17: 0}(1 \cdot 72 \%)$, $\mathrm{C}_{17: 1}(1 \cdot 72 \%), \mathrm{C}_{18: 0}(7 \cdot 32 \%)$ and $\mathrm{C}_{18: 1}(7 \cdot 76 \%)$. Mycolic acids are absent.

The type strain is SNG49 ${ }^{\mathrm{T}}\left(=\mathrm{DSM} 44442^{\mathrm{T}}=\right.$ NRRL B$24244^{\mathrm{T}}$ ), isolated from marine sediments at a depth of $20 \mathrm{~cm}$ on the seashore of Abu Qir Bay, west of Alexandria, Egypt.

\section{Acknowledgements}

We thank Ina Kramer, Gabriele Pötter, Bettina Sträubler and Jolantha Swiderski for technical assistance.

\section{References}

Al-Tai, A. M. \& Ruan, J.-S. (1994). Nocardiopsis halophila sp. nov., a new halophilic actinomycete isolated from soil. Int J Syst Bacteriol 44, 474-478.

Al-Zarban, S. S., Abbas, I., Al-Musallam, A. A., Steiner, U., Stackebrandt, E. \& Kroppenstedt, R. M. (2002). Nocardiopsis halotolerans sp. nov., isolated from salt marsh soil in Kuwait. Int J Syst Evol Microbiol 52, 525-529.

Cashion, P., Holder-Franklin, M. A., McCully, J. \& Franklin, M. (1977). A rapid method for the base ratio determination of bacterial DNA. Anal Biochem 81, 461-466.

Chun, J., Bae, K. S., Moon, E. Y., Jung, S.-O., Lee, H. K. \& Kim, S.-J. (2000). Nocardiopsis kunsanensis sp. nov., a moderately halophilic actinomycete isolated from a saltern. Int J Syst Evol Microbiol 50, 1909-1913.

De Soete, G. (1983). A least squares algorithm for fitting additive trees to proximity data. Psychometrika 48, 621-626.

Evtushenko, L. I., Taran, V. V., Akimov, V. N., Kroppenstedt, R. M., Tiedje, J. M. \& Stackebrandt, E. (2000). Nocardiopsis tropica sp. nov., Nocardiopsis trehalosi sp. nov., nom. rev. and Nocardiopsis dassonvillei subsp. albirubida subsp. nov., comb. nov. Int J Syst Evol Microbiol 50, 73-81.

Felsenstein, J. (1993). PHYLIP (phylogenetic inference package), version 3.5c. Department of Genetics, University of Washington, Seattle, WA, USA.

Huß, V. A. R., Festl, H. \& Schleifer, K. H. (1983). Studies on the spectrophotometric determination of DNA hybridization from renaturation rates. Syst Appl Microbiol 4, 184-192.

Jahnke, K. D. (1992). Basic computer program for evaluation of spectroscopic DNA renaturation data from GILFORD System 2600 spectrometer on a PC/XT/AT type personal computer. J Microbiol Methods 15, 61-73.
Kroppenstedt, R. M. (1982). Separation of bacterial menaquinones by HPLC using reverse phase (RP-18) and a silver loaded ion exchanger. J Liq Chromatogr 5, 2359-2367.

Kroppenstedt, R. M. (1985). Fatty acid and menaquinone analysis of actinomycetes and related organisms. In Chemical Methods in Bacterial Systematics, pp. 173-179. Edited by M. Goodfellow \& D. E. Minnikin. London: Academic Press.

Kroppenstedt, R. M. \& Evtushenko, L. I. (2002). The family Nocardiopsaceae. In The Prokaryotes: an Evolving Electronic Database for the Microbial Community, 3rd edn (release 3.11). Edited by M. Dworkin and others. New York: Springer. http://www.prokaryotes.com

Lechevalier, M. P. \& Lechevalier, H. A. (1980). The chemotaxonomy of actinomycetes. In Actinomycete Taxonomy, Special Publication 6, pp. 227-291. Arlington, VA: Society for Industrial Microbiology.

Lechevalier, M. P., De Bièvre, C. \& Lechevalier, H. A. (1977). Chemotaxonomy of aerobic actinomycetes: phospholipid composition. Biochem Syst Ecol 5, 249-260.

Maidak, B. L., Cole, J. R., Parker, C. T., Jr \& 11 other authors (1999). A new version of the RDP (Ribosomal Database Project). Nucleic Acids Res 27, 171-173.

Meyer, J. (1994). The Genus Nocardiopsis Meyer 1976. In Bergey's Manual of Determinative Bacteriology, 9th edn, pp. 2562-2568. Edited by J. G. Holt, N. R. Krieg, P. H. A. Sneath, J. T. Staley \& S. T. Williams. Baltimore: Williams \& Wilkins.

Miller, L. T. (1982). Single derivatization method for routine analysis of bacterial whole-cell fatty acid methyl esters, including hydroxy acids. J Clin Microbiol 16, 584-586.

Minnikin, D. E., Alshamaony, L. \& Goodfellow, M. (1975). Differentiation of Mycobacterium, Nocardia and related taxa by thin-layer chromatographic analysis of whole-organism methanolysates. J Gen Microbiol 88, 200-204.

Minnikin, D. E., Patel, P. V., Alshamaony, L. \& Goodfellow, M. (1977). Polar lipid composition in the classification of Nocardia and related bacteria. Int J Syst Bacteriol 27, 104-117.

Minnikin, D. E., O'Donnell, A. G., Goodfellow, M., Alderson, G., Athalye, M., Schaal, K. \& Parlett, J. H. (1984). An integrated procedure for the extraction of bacterial isoprenoid quinones and polar lipids. J Microbiol Methods 2, 233-241.

Peltola, J. S. P., Andersson, M. A., Kämpfer, P., Auling, G., Kroppenstedt, R. M., Busse, H.-J., Salkinoja-Salonen, M. S. \& Rainey, F. A. (2001). Isolation of toxigenic Nocardiopsis strains from indoor environments and description of two new Nocardiopsis species, $N$. exhalans sp. nov. and $N$. umidischolae sp. nov. Appl Environ Microbiol 67, 4293-4304.

Rainey, F. A., Ward-Rainey, N., Kroppenstedt, R. M. \& Stackebrandt, E. (1996). The genus Nocardiopsis represents a phylogenetically coherent taxon and a distinct actinomycete lineage: proposal of Nocardiopsaceae fam. nov. Int J Syst Bacteriol 46, 1088-1092.

Sasser, M. (1990). Identification of bacteria by gas chromatography of cellular fatty acids. USFCC Newsl 20, 1-6.

Schippers, A., Bosecker, K., Willscher, S., Spröer, C., Schumann, P. \& Kroppenstedt, R. M. (2002). Nocardiopsis metallicus sp. nov., a metal-leaching actinomycete isolated from an alkaline slag dump. Int J Syst Evol Microbiol 52, 2291-2295.

Shirling, E. B. \& Gottlieb, D. (1966). Methods for characterization of Streptomyces species. Int J Syst Bacteriol 16, 313-340.

Staneck, J. L. \& Roberts, G. D. (1974). Simplified approach to identification of aerobic actinomycetes by thin-layer chromatography. Appl Microbiol 28, 226-231.

Wayne, L. G., Brenner, D. J., Colwell, R. R. \& 9 other authors (1987). International Committee on Systematic Bacteriology. Report of the ad hoc committee on reconciliation of approaches to bacterial systematics. Int J Syst Bacteriol 37, 463-464. 